\title{
Effect of chlorhexidine, honey and Propolis on Streptococcus mutans Counts: in vitro Study
}

\author{
Abdulrhman Alkhaled ${ }^{1}$, Laith Alsabek ${ }^{2}$, Maher Al-assaf ${ }^{3}$, Faek Badr ${ }^{1}$ \\ ${ }^{1}$ Department of Pediatric Dentistry, Faculty of Dentistry, Tishreen University, Syria. \\ 2 Faculty of Dentistry, Damascus University, Damascus, Syria. \\ ${ }^{3}$ Department of Oral Histology and Pathology, Faculty of Dentistry, Damascus University, Damascus, Syria.
}

\section{Abstract}

Objective: Streptococcus mutans is considered one of the bacteria that causes necrosis, as it metabolism sugar to obtain energy, producing an acidic environment and causing depression in the enamel surface, which causes the dissolution of the calcium molecule, a problem of cavited in the tooth; so the aim of the research is to evaluate the effect of mouthwashes chlorhexidine $0.12 \%$ - honey $50 \%$ - propolis $5 \%$ on Streptococcus mutans in children.

Study design: A laboratory study to assess the efficiency of chlorhexidine, honey and Propolis on Streptococcus mutans counts. The sample included 60 children divided into: $\mathrm{G} 1$ (Chlorhexidine $0.12 \%=$ 20 children), G2 (Propolis 5\% = 20 children), G3 (Honey 100\% = 20 children). The data was analyzed using the statistical analysis program SPSS, version 13.00 , at a confidence level of $95 \%$ ( $P<0.05$ (. Paired sample $T$ test was used to compare the variable means of the values of the studied variables.

Results: There is significant difference between three groups. The reduction ratio was $89.97 \%$ in G1, $85.49 \%$ in G2 and $76.29 \%$ in G3.
Conclusion: This study demonstrated the effectiveness of mouthwashes of chlorhexidine, propolis and honey on the bacteria of Streptococcus mutans.

Keywords: Streptococcus mutans; chlorhexidine; propolis; honey

Citation: Alkhaled A, et al. (2021) Effect of chlorhexidine, honey and Propolis on Streptococcus mutans Counts: in vitro Study. Dentistry $3000 . \quad 1: a 001$ doi:10.5195/d3000.2021.166 Received: April 03, 2021

Accepted: April 21, 2021

Published: November 19, 2021

Copyright: (02021 Alkhaled A, et al. This is an open access article licensed under a Creative Commons Attribution Work 4.0 United States License. Email: dr.maher.assaf1990@gmail.com

\section{Introduction}

Streptococcus mutans are grampositive bacteria of oval or aciduric shapes that are lined up in the form of acidogenic and aciduric nodules or swabs. They survive at low $\mathrm{pHs}$ and also metabolize carbohydrates in an acid medium [1]. Streptococcus mutans grows at temperatures ranging between 18-40 degrees Celsius, and it is considered one of the bacteria that causes necrosis, as it metabolism sugar to obtain energy, producing an acidic environment and causing depression in the enamel surface, which causes the dissolution of the calcium molecule, a problem of cavited in the tooth [2]. It found that Streptococcus mutans is more prevalent in pit and groove and there are a few of them on the buccal surfaces, where the mutant streptococcus forms $39 \%$ of the total streptococci within the oral cavity [3]. A study by Köhler et al.1948 indicated a relationship between early colonization of the Streptococcus mutans in the mouths of children and a high rate of caries [4], Whereas Aas et al. 2008 study showed that Streptococcus mutans is mainly responsible for the initiation of dental caries despite the involvement of other oral bacteria in the development of dental caries such as Lactobacillus and Veillonella [5]. There are two types of oral washes (chemical and 
herbal). Chlorhexidine is chemical. While many plant extracts have antibacterial properties, they are used effectively in oral hygiene. Natural herbs such as miswak, honey, coconut oil, ginger, clove oil, and many other types [6].

For a long time, chlorhexidine has been the most widely used oral washes for reducing plaque and gingivitis, and there is no difference between an alcoholbased or a water-based lotion, and it is considered the gold standard among oral washes [7] , Chlorhexidine is considered a broad-spectrum antibacterial against Gram-positive and Gramnegative bacteria, fungi, and some viruses, and it has an active effect against Streptococcus mutans [8].

Propolis or what is known as bee gum or glue is a natural resinous substance that bees collect from the buds and parts of the plant, mixed with bee enzymes, pollen and wax. It has a complex formula with a wide range of antibacterial, antiviral, antifungal, and antioxidant effects [9].

Propolis has important uses in dentistry and preventive oral medicine, as studies in this field have shown the protective ability of propolis extracts when used to reduce the amount of bacterial plaque, thus reducing dental caries [10], Barrientos et al 2013 confirmed the promising efficacy of propolis in the prevention of dental caries and some diseases of the oral cavity, when they demonstrated the bio-efficacy of the ethanoli extract and metanoli of the Chilean propolis samples against the bacteria that cause caries , Streptococcus sobrinus and Streptococcus mutans [11] , honey is a natural, viscous, sweettasting food compound, ranging in color from light brown to dark, resulting from the collection of nectar flowers or sugar secretions from some trees by bees and the addition of compounds to it that these bees secrete [12].

Honey has antibacterial activity which is proven as honey is a broad-spectrum inhibitor of many types of bacteria , including aerobic and anaerobic bacteria , the pros and cons of bacteria, as one laboratory study showed that methanol, ethanol, and ethyl acetate extracted from honey showed antibacterial activity against Gram-positive (Staphylococcus aureus, Bacillus subtilis, Bacillus cereus, Enterococcus faecalis) and against Gram-negative bacteria (Escherichia coli, Pseudomonas aeruginosa, Salmonella typhi) [13].

The aim of this study is to evaluate the effect of mouthwashes chlorhexidine $0.12 \%$ - honey $50 \%$ - propolis 5\% on Streptococcus mutans in children.

\section{Material and Methods}

The sample included 60 children (30 males - 30 females) aged between 6-9.

The Tishreen University Research and Ethics Committee at the Faculty of Medicine and Dentistry approved the study protocol, and subjects gave their informed consent to participate. The study was conducted in accordance with the CONSORT statement.

Inclusion criteria: Cooperative Children aged from 6 to 9 years old. Healthy patients with no history of previous systematic diseases that can affect their oral health.

Exclusion criteria: Patients with gingivitis, having fixed or movable braces, and children who is taking any antibiotic before enrollment.

Inform consent was taken from the volunteers before starting the study according to a special form designed for the research that includes details of the research and the materials used in the research.

We used local products that are widespread in pharmacies. The children were divided into 3 groups, each group containing 20 
children (20 chlorhexidine - 20 honey - 20 propolis).

Saliva collection mechanism: [14]

The child was brought to the clinic and the guardian requested the following:

Avoiding food with a high content of acids and sugars 60 minutes before work in order to cause it to reduce the $\mathrm{pH}$ of saliva, which leads to an increase in bacterial growth. And, avoiding foods and drinks containing caffeine for 12 hours before work. That the sample be collected between 9 12 p.m. Emphasis on not brushing the teeth on the same day in order to preserve the oral flora and not to have bleeding that affects the accuracy of reading the results. Patients did not use any oral rinse or paste containing chlorhexidine 7 days before the start of the clinical procedures.

A first saliva sample was taken before using rinsing by using a sterile salivary swab for this procedure. The swab included passing the swab head over the vestibular surfaces of the teeth, the palate, the floor of the mouth, and the vestibule of the cheek.

Then, the child was asked to rinse his mouth with solution using 10 $\mathrm{ml}$ of solution for a period of time (30) seconds, after that, we took a second swab for the child, similar to its procedures for the first one, and the child's data were recorded on it (name - age - gender - swab before / after) on each cotton swab and sent to the bacterial culture laboratory at Hama National Hospital - Hama city Syria, to start the laboratory work procedures.

Chlorhexidine sample (20 children) The product used is a $0.12 \%$ chlorhexidine solution ready for use, produced by a national company.

Propolis sample (20 children) The product used is a $5 \%$ propolis solution ready for use, produced by a national company.

Honey sample (20 children) The honey was $100 \%$ concentrated from the packing of a national company. We drew $5 \mathrm{ml}$ of honey and added it to $5 \mathrm{ml}$ of distilled water in a sterile sample collection package, and we mixed it and then gave it to the child to rinse with it.

Procedures for bacterial culture in the laboratory:

\section{Sampling extension:}

We dilate the saliva samples in two stages to reduce the bacterial load for ease of counting, provided that the real concentration of germs is calculated later as follows:
Stage one: Use of 10000

microliters $(10 \mathrm{ml})$ of salin by disposable one use syringe and put it in the glass tube. Then, we remove 100 microns. Thus, we get 9900 microliters in the tube. Then we add 100 microns of the saliva sample by micropipette. Finally, we get dilate of saliva sample in $1 / 100$ radio; $10-2$. Then we mixed the homogenous dilate saliva sample on viberator for 30 seconds.

Stage two: Repeating the previous stages but by adding 100 microliters of dilate solution to 9900 microliters from the saline in the other glass tube and the ratio became 1/ 10000 and then repeated this homogenous process by vibrator.

\section{Bacterial culture:}

Culture medium: Preparation of the culture medium for Streptococcus mutans. We add 90 $\mathrm{g}$ of Mitis Salivarius Agar (MSA) powder to 1 liter $(1000 \mathrm{ml})$ of distilled water, then sterilize it in Autoclave at $121 \mathrm{C}$ for 20 minutes under $15 \mathrm{lbs}$ pressure, and when cooled to a temperature of $45-50^{\circ}$ C, $1 \mathrm{ml}$ of $1 \%$ Potassium tellurite solution is added to it, mixing the components well and pouring the mixture into sterile Petri dishes in the airflow chamber, according to the instructions of the 
manufacturer of the culture medium.

Culture method: we take 10 microliters of dilate solution by micropipette. And then we spread it on the surface of culture media in Petri dish by sterilize platin loop tool in way that we get a distinct bacterial colony. And placed upside down within the incubator at $37^{\circ} \mathrm{C}$ for 48 hours in the presence of $5-10 \%$ of carbon dioxide.

Bacterial appearance: The MSA culture medium performs selective isolation of Streptococcus mitis, Streptococcus salivirus, Streptococcus mutans, Streptococcus sanguis, Enterococci.

\section{Streptococcus mutans appear} convex, crested, blue, pale, with a grainy appearance, As shown in figure 1 and figure 2 .

Colonies counting: we count the colonies by using An Electron microscope, After the colonies counting is complete. This number presents the number of colonies in 10 dilate microliter. Thus, we multiply this number with 10000 which is the dilation ratio then we divide the number by 1000 to get the final number of bacterial colonies in $\mathrm{ml}$ (CFU/ml).

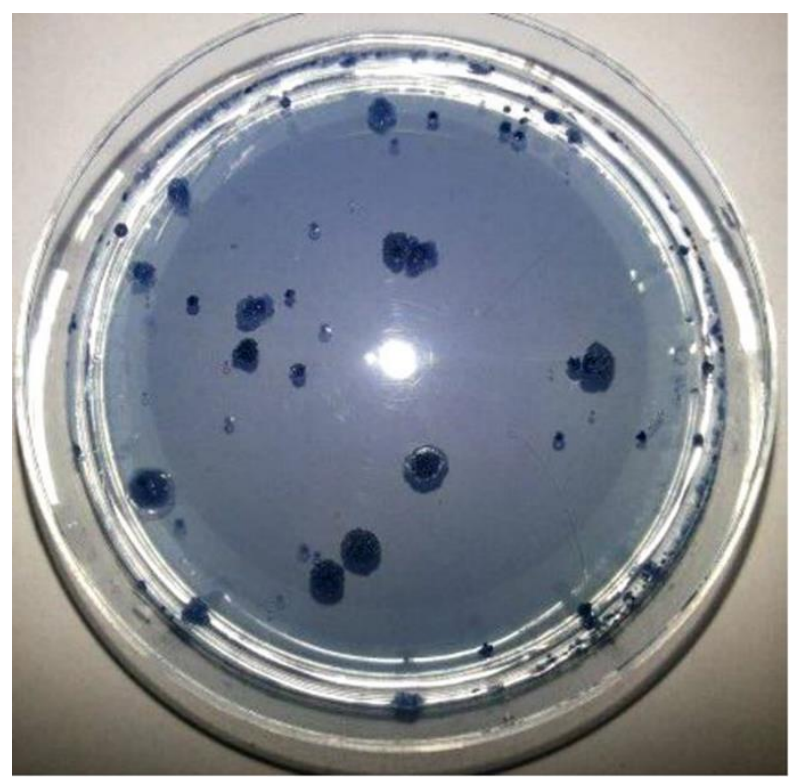

Figure 1 Indicates the number of Streptococcus mutans before applying honey.
Figure $\mathbf{2}$ Indicates the number of Streptococcus mutans after applying honey.
Statistical analysis: The data were analyzed using the statistical analysis program SPSS, version 13.00 , at a confidence level of $95 \%$ (P $<0.05$ ).

We used Paired sample $T$ test to compare the variable means of the values of the studied variables.

\section{Results}

Table No. 1 shows descriptive statistical measures of the number of Streptococcus mutans among the 60 patients ( 20 patients in each group), while Fig. No. (3) shows the arithmetic averages of the number of Streptococcus mutans in the research patients. 
Table No. 2 shows the results of using Paired Samples T Test when comparing the arithmetic means of the number of Streptococcus mutans in each patient group before and after the experiment.
Table No. 3 shows the percentages of the amount of decrease in number of Streptococcus mutans between the two times (before using the substance and after using the substance) between the three experimental groups.
As for Figure No. 4, it shows the percentage values of the amount of decrease in number of Streptococcus mutans between the two times (before using the substance and after using the substance) between the three experimental groups.

Table No 1. Statistical measures of the number of Streptococcus mutans in the research patients

\begin{tabular}{|c|c|c|c|c|c|c|}
\hline Material & Sample & Studied variables & mean & SD & $\begin{array}{l}\text { minimal } \\
\text { value }\end{array}$ & $\begin{array}{c}\max \\
\text { value }\end{array}$ \\
\hline \multirow{2}{*}{ Honey } & \multirow{2}{*}{20} & $\begin{array}{c}\text { number of Streptococcus mutans before using } \\
\text { honey }\end{array}$ & 161.30 & 43.11 & 96 & 222 \\
\hline & & $\begin{array}{l}\text { number of Streptococcus mutans after using } \\
\text { honey }\end{array}$ & 38.25 & 10.23 & 23 & 53 \\
\hline \multirow{2}{*}{ propolis } & \multirow{2}{*}{20} & $\begin{array}{l}\text { number of Streptococcus mutans before using } \\
\text { propolis }\end{array}$ & 158.45 & 40.24 & 101 & 222 \\
\hline & & $\begin{array}{l}\text { number of Streptococcus mutans after using } \\
\text { propolis }\end{array}$ & 15.90 & 4.48 & 9 & 25 \\
\hline \multirow{2}{*}{ chlorhexidine } & \multirow{2}{*}{20} & $\begin{array}{l}\text { number of Streptococcus mutans before using } \\
\text { chlorhexidine }\end{array}$ & 173.70 & 33.87 & 117 & 250 \\
\hline & & $\begin{array}{c}\text { number of Streptococcus mutans after using } \\
\text { chlorhexidine }\end{array}$ & 25.20 & 4.94 & 17 & 37 \\
\hline
\end{tabular}

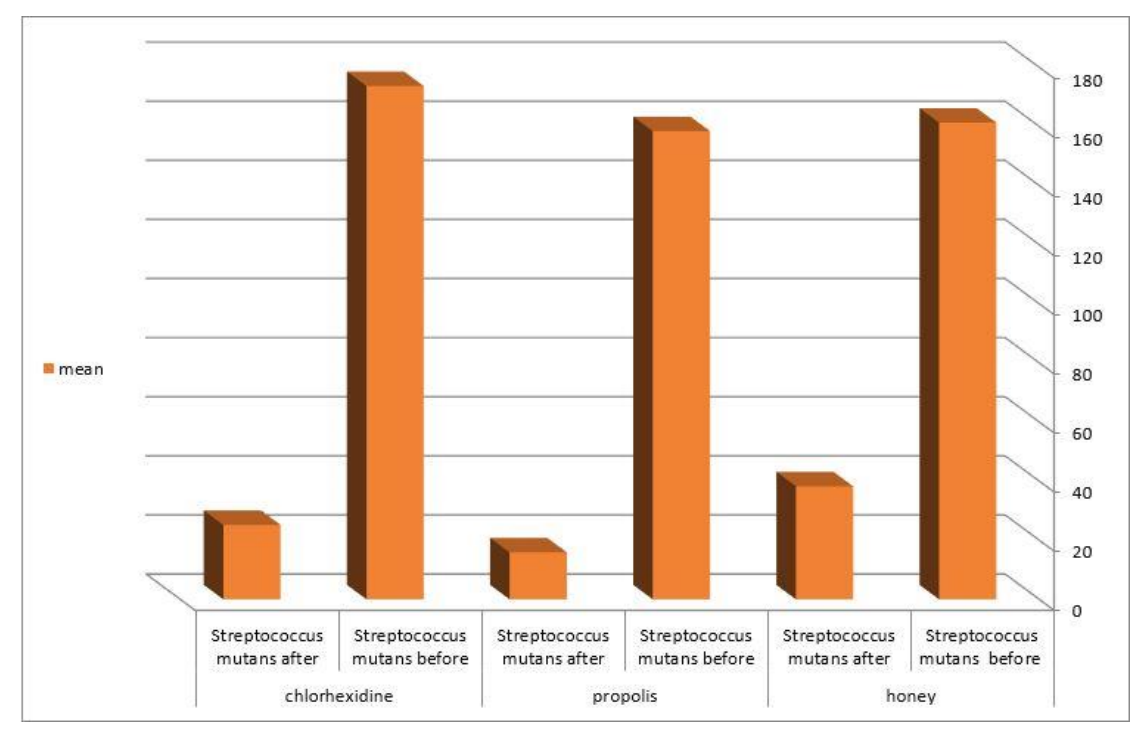

Figure 3 Mean of the number of Streptococcus mutans in the research patients. 
Table No. 2. Results of using Paired Samples T Test when comparing the arithmetic means of the number of Streptococcus mutans before and after the experiment.

\begin{tabular}{|c|c|c|c|c|c|c|c|}
\hline Materials & & Comparisons & $\begin{array}{l}\text { difference } \\
\text { between }\end{array}$ & $\begin{array}{c}\mathrm{T} \\
\text { Test value }\end{array}$ & df & P-value & SIG \\
\hline Honey & Pair 1 & $\begin{array}{l}\text { number of } \\
\text { Streptococcus mutans } \\
\text { before using honey - } \\
\text { number of } \\
\text { Streptococcus mutans } \\
\text { after using honey }\end{array}$ & 123.05 & 16.731 & 19 & 0.000 & * \\
\hline propolis & Pair 1 & $\begin{array}{c}\text { number of } \\
\text { Streptococcus mutans } \\
\text { before using propolis - } \\
\text { number of } \\
\text { Streptococcus mutans } \\
\text { after using propolis }\end{array}$ & 148.50 & 22.876 & 19 & 0.000 & * \\
\hline chlorhexidine & Pair 1 & $\begin{array}{c}\text { number of } \\
\text { Streptococcus mutans } \\
\text { before using } \\
\text { chlorhexidine - number } \\
\text { of Streptococcus } \\
\text { mutans after using } \\
\text { chlorhexidine }\end{array}$ & 142.55 & 17.428 & 19 & 0.000 & * \\
\hline
\end{tabular}

sig: significance.

*: statistically significant. 
Table No. 3. The percentages of the amount of decrease in number of Streptococcus mutans between the two times (before using the substance and after using the substance) between the three experimental groups.

\begin{tabular}{|c|c|c|c|c|c|}
\hline Materials & $\begin{array}{l}\text { Number of } \\
\text { patients }\end{array}$ & $\begin{array}{c}\text { Streptococcus mutans } \\
\text { variable value before using } \\
\text { the material }\end{array}$ & $\begin{array}{c}\text { Streptococcus mutans } \\
\text { variable value after using the } \\
\text { material }\end{array}$ & $\begin{array}{l}\text { The amount } \\
\text { of decrease }\end{array}$ & $\begin{array}{c}\text { Reduction ratio } \\
\%\end{array}$ \\
\hline Honey & 20 & 161.30 & 38.25 & 123 & $76.29 \%$ \\
\hline Propolis & 20 & 173.70 & 25.20 & 149 & $85.49 \%$ \\
\hline Chlorhexidine & 20 & 158.45 & 15.90 & 143 & $89.97 \%$ \\
\hline Total & 60 & 164.48 & 39.167 & 125 & $76.19 \%$ \\
\hline
\end{tabular}

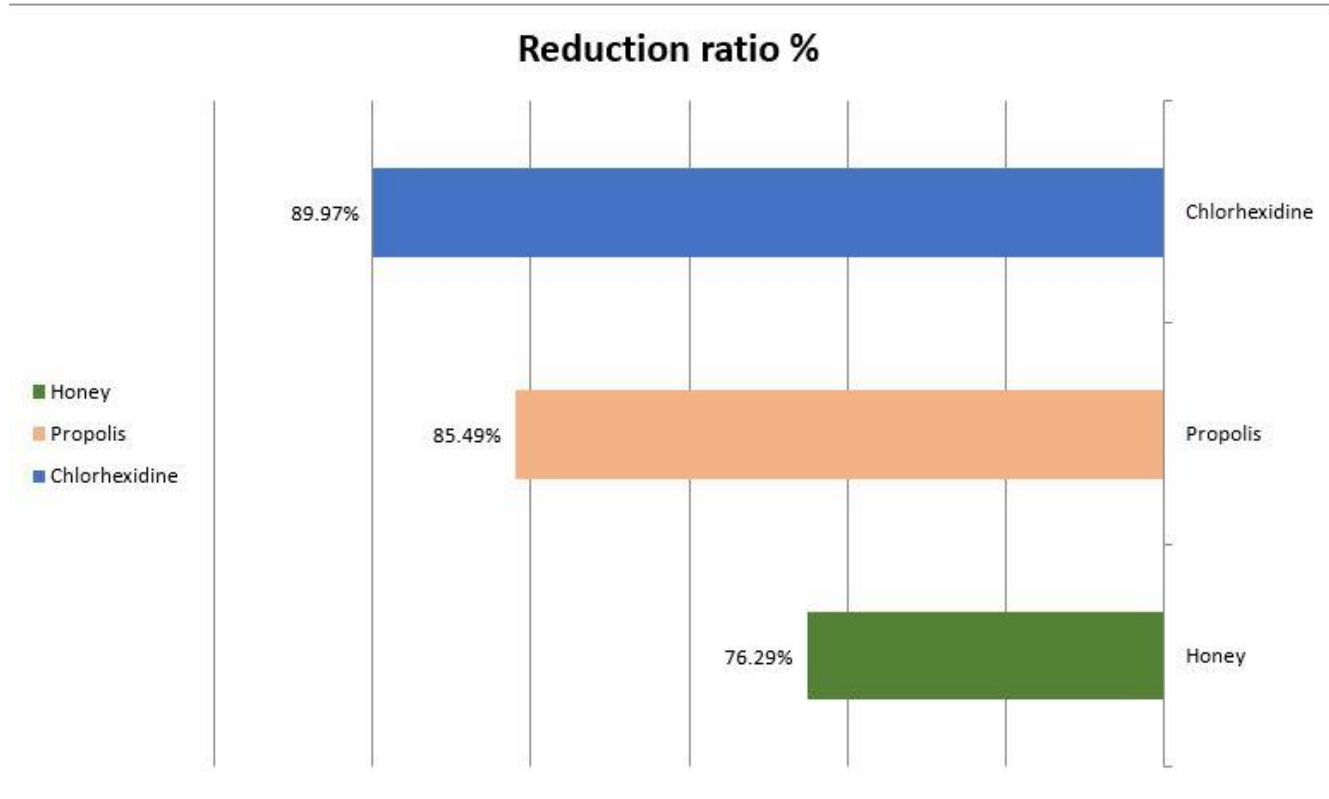

Figure 4 The percentages of the amount of decrease in number of Streptococcus mutans between the two times (before using the substance and after using the substance) between the three experimental groups.

\section{Discussion}

The saliva count is a reasonable indicator of a complete bacterial load in the oral cavity, and the count of Streptococcus mutans or Lactobacillus in total dental plaque samples does not explain the variation in the incidence of caries as well as it does when counted in induced saliva [15].

In this study we studied the count of Streptococcus mutans in saliva because there is an association between the count of Streptococcus mutans in saliva and the occurrence of dental caries in children, and often there is a correlation between the levels of the Streptococcus mutans and caries activity. Identification persons with a high risk of caries [16].

bacteria have developed antibiotic-resistant strains, and 
pharmaceutical factories found it difficult to develop new antibacterial agents to meet this new challenge due to the high costs of drug research, which prompted researchers to search for an alternative to low-cost natural materials [17].

Reports have shown the efficacy of honey against a wide spectrum of clinically resistant multibacteria, so its use has emerged as a promising alternative to industrial pharmaceutical products [17].

The rate of decrease in the count of Streptococcus mutans was statistically significant after one minute of using chlorhexidine, as it reached $89.97 \%$, and in propolis it was $85.49 \%$, and in honey it was $76.29 \%$.

The results of this study showed that the three oral rinse had an immediate and direct effect on the bacteria of the Streptococcus mutans, as chlorhexidine had a higher direct efficacy on the count of Streptococcus mutans, then propolis and then honey.

The results of this study regarding the antibacterial effect of honey oral washes are in agreement with the results of Rupesh et al. 2014, which confirmed the antibacterial properties of New Zealand honey oral washes [18].
The results of our study also agreed with the study of Nassar and colleagues 2012, where they compared natural honey with synthetic honey in its effect on the Streptococcus mutans found in plaque, and found the effect of natural honey much higher than synthetic [19], This negates the effect of the high sugar content in honey on the oral bacteria.

We agreed with the results of Hegde and colleagues' 2013 study in which they indicated that propolis has anti-Streptococcus mutans activity in the oral cavity and can be used as a measure to prevent dental caries [20].

We also agreed with the results of the study by Elbaz and colleagues 2012, where the study compared New Zealand honey and Egyptian propolis extract on Streptococcus mutans and Lactobacillu, and the study Draw a Conclusion that Egyptian propolis was superior to New Zealand honey in affecting the count of Streptococcus mutans and Lactobacillus [21].

The results of our study on the effect of chlorhexidine on Streptococcus mutans are in agreement with the results of the Fredri Lundström and Krasse 1987 study where the use of chlorhexidine reduced the count of Streptococcus mutans in fixed orthodontic patients [22].

\section{Conclusion}

This study demonstrated the effectiveness of mouthwashes of chlorhexidine, propolis and honey on the bacteria of Streptococcus mutans. The results of the present study showed the effectiveness of chlorhexidine mouthwashes $0.12 \%$ - honey $50 \%$ - propolis $5 \%$ in reducing oral bacterial count rates. Chlorhexidine showed the maximum effectiveness, followed by propolis, then honey.

\section{Acknowledgment}

None.

\section{References}

1. Dental caries is a preventable infectious disease. Balakrishnan $\mathrm{M}$, Simmonds RS, Tagg JR. Aust Dent J. 2000 Dec;45(4):235-245. doi: 10.1111/j.1834-7819.2000.tb00257.x. PMID: 11225524.

2. Streptococcus mutans, caries and simulation models. Forssten SD, Björklund $M$, Ouwehand AC. Nutrients. 2010 Mar;2(3):290-298. doi: 10.3390/nu2030290. PMID: 22254021.

3. Mode of delivery and other maternal factors influence the acquisition of Streptococcus mutans in infants. Li Y, Caufield PW, Dasanayake AP, Wiener HW, Vermund SH. J Dent Res. 2005 Sep;84(9):806-811. doi: $10.1177 / 154405910508400905$. PMID: 16109988. 
4. The effect of caries-

preventive measures in mothers on dental caries and the oral presence of the bacteria Streptococcus mutans and lactobacilli in their children. Köhler B, Andréen I, Jonsson B. Arch Oral Biol. 1984 29(11):879-883. doi: 10.1016/0003-9969(84)90086-4.

PMID: 6596034.

5. Bacteria of dental caries in primary and permanent teeth in children and young adults. Aas JA, Griffen AL, Dardis SR, Lee AM, Olsen I, Dewhirst FE, Leys EJ, Paster BJ. J Clin Microbiol. 2008 Apr;46(4):1407-1417. doi: 10.1128/JCM.01410-07. PMID: 18216213.

6. In vitro amoebicidal effect of Aloe vera ethanol extract and honey against Acanthamoeba spp. cysts. Kadry GM, Ismail MAM, El-Sayed NM, El-Kholy HS, El-Akkad DMH. J Parasit Dis. 2021 Mar;45(1):159-168. doi: 10.1007/s12639-020-01292-8. PMID: 33746401.

7. Evaluation of new seawaterbased mouth rinse versus chlorhexidine $0.2 \%$ reducing plaque and gingivitis indexes. a randomized controlled pilot study. Calvo-Guirado $J L$, Fernandez Dominguez $M$, Aragoneses JM, Martinez Gonzalez JM, Fernández-Boderau E, GarcésVillalá MA, et al. Appl. Sci. 2020

Feb;10(3):982. doi: 10.3390/app10030982.

8. Adjunctive use of chlorhexidine in oral candidoses: a review. Ellepola AN, Samaranayake
LP. Oral Dis. 2001 Jan;7(1):11-17. PMID: 11354914.

9. Management strategies of honey bee diseases. Arbia A, Babbay B. Journal of Entomology. 2011 ;8(1):1-15. doi: 10.3923/je.2011.1.15.

10. Does propolis help to maintain oral health?. Więckiewicz W, Miernik M, Więckiewicz M, Morawiec T. Evid Based Complement Alternat Med. 2013 jan;2013:351062. doi: 10.1155/2013/351062. PMID: 23365605.

11. Chemical and botanical characterization of Chilean propolis and biological activity on cariogenic bacteria Streptococcus mutans and Streptococcus sobrinus. Barrientos L, Herrera CL, Montenegro G, Ortega X, Veloz J, Alvear M, Cuevas A, Saavedra N, Salazar LA. Braz J Microbiol. 2013 Oct 30;44(2):577-585. doi: 10.1590/S1517-83822013000200038. PMID: 24294257.

12. Clinical usage of honey as a wound dressing: an update. Molan PC, Betts JA. J Wound Care. 2004 Oct;13(9):353-356. doi: 10.12968/jowc.2004.13.9.26708. PMID: 15517742.

13. Antibacterial efficacy of raw and processed honey. Mohapatra DP, Thakur V, Brar SK. Biotechnol Res Int. 2011 Dec;2011:917505. doi: 10.4061/2011/917505. PMID: 21350671.

14. Individual differences in salivary cortisol: associations with common over-the-counter and prescription medication status in infants and their mothers. Hibel LC, Granger DA, Kivlighan KT, Blair C. Horm Behav. 2006 Aug;50(2):293300. doi: 10.1016/j.yhbeh.2006.03.014. PMID: 16682032.

15. Number of mutans streptococci or lactobacilli in a total dental plaque sample does not explain the variation in caries better than the numbers in stimulated whole saliva. Sullivan A, Borgström MK, Granath L, Nilsson G. Community Dent Oral Epidemiol. 1996 Jun;24(3):159-163. doi: 10.1111/j.1600-0528.1996.tb00834.x. PMID: 8871012

16. Caries risk assessment from dental plaque and salivary Streptococcus mutans counts on two culture media. Sánchez-Pérez L, Acosta-Gío AE. Arch Oral Biol. 2001 Jan;46(1):49-55. doi: 10.1016/s00039969(00)00095-9. PMID: 11163595.

\section{Antibacterial activity of} selected Malaysian honey. Zainol MI, Mohd Yusoff K, Mohd Yusof MY. BMC Complement Altern Med. 2013 Jun;13:129. doi: 10.1186/1472-688213-129. PMID: 23758747.

18. Evaluation of the effects of manuka honey on salivary levels of mutans streptococci in children: a pilot study. Rupesh S, Winnier JJ, Nayak UA, Rao AP, Reddy NV, Peter J. J Indian Soc Pedod Prev Dent. 2014 Jul-Sep;32(3):212-219. doi: 
Vol 9 No 1 (2021) DOI 10.5195/d3000.2021.166

10.4103/0970-4388.135827. PMID:

25001440.

19. Effect of honey on

Streptococcus mutans growth and

biofilm formation. Nassar HM, Li M,

Gregory RL. Appl Environ Microbiol.

2012 Jan;78(2):536-540. doi:

10.1128/AEM.05538-11. PMID:

22038612.

20. Effect of Propolis on

Streptococcus mutans Counts: An in vivo Study. Hegde KS, Bhat SS, Rao A, Sain S. Int J Clin Pediatr Dent. 2013 Jan;6(1):22-25. doi: 10.5005/jpjournals-10005-1180. PMID:

25206182.

21. Comparison of the antimicrobial effect of Egyptian propolis vs New Zealand propolis on Streptococcus mutans and lactobacilli in saliva. Elbaz GA, Elsayad II. Oral Health Prev Dent. 2012;10(2):155160. doi: 10.3290/j.ohpd.a28003. PMID: 22763595.

\section{Streptococcus mutans and}

lactobacilli frequency in orthodontic patients; the effect of chlorhexidine treatments. Lundström F, Krasse B.

Eur J Orthod. 1987 May;9(2):109-116. doi: 10.1093/ejo/9.2.109. PMID:

3472888. 